\title{
Analysis on Distributions of Problem Phenomena in Engineering Project
}

\author{
Chen $\mathrm{He}^{1, *}$ and Xueliang $\mathrm{Hou}^{2}$ \\ ${ }^{1} \mathrm{Xi}$ 'an architecture and technology university, Shaanxi province, China \\ ${ }^{2}$ Institute of engineering management, North China electric power university, Beijing, China \\ ${ }^{*}$ Corresponding author
}

\begin{abstract}
In different stages of engineering projects, there are many problems which appear frequently, always produce disadvantages to projects and bring many barriers to engineering project managers. In this paper, for the purpose of solving these problems, the problem phenomena in engineering projects have been investigated. The corresponding characteristics and relationships of all problem phenomena are discovered by statistical analysis. The results show that the serious phase of engineering conflict events in construction projects and an obviously increase of problem phenomena amount from decisionmaking stage to arranged stage. The results put forward a significant evidence for project managers to approach engineering problems effectively.
\end{abstract} project

Keywords-distribution law; problem phenomena; engineering

\section{INTRODUCTION}

In the implementing process of engineering projects (CEP), there are many indeterminate factors which always bring disadvantage to projects. They often show in various forms in engineering projects just like illness phenomena in medicine. Because of these problems' randomization and variety, project managers could not be easy to find out their characteristics and distribution regulations, and it is more difficult to forecast and control them. Once these problems happen in engineering projects, they might result in unqualified engineering, delay in schedule or higher engineering cost, and project failure in the worst case [1]. So, how to find out these problems is very important for engineering project managers.

\section{StATISTICS AND ANALYSIS OF INVESTIGATION RESUltS}

If these problems in CEP are named as morbidity phenomena, the first task is investigation to these morbidity phenomena before analyzing them. In order to make the investigation result have universality and representative, 575 project managers in 35 building companies at different districts in china have been visited, and 6782 samples with a large amount of confirmatory information which can represent and describe engineering morbidity phenomena are obtained. It can be seen from the investigation results obviously that these morbidity phenomena not only have many categories and large amounts, but also are very disorder on the surface. This shows that these morbidity phenomena have a characteristic of variety. So, these morbidity phenomena should be analyzed from the macro point of view firstly by classifiable method.
Generally, engineering project is made up of four stages, which are decision-making stage, arranged stage, construction stage and conclusion stage [2]. All projects' plans and objects will be implemented step by step from first stage to last stage, so, it can be sure that all problem phenomena in engineering projects would correlate with their corresponding plans and objects tightly. This means all problem phenomena can be compartmentalized into the four stages. Based on which, some problem phenomena with same characteristic in one stage can also be united by apriority [3].

According to the method, it can be known that representational problem phenomena in CEP have 22 categories 260 subcategories, which are 4 categories and 22 subcategories in decision-making stage, 6 categories and 65 subcategories in arranged stage, 7 categories and 144 subcategories in construction stage and 5 categories 29 subcategories in the last stage. All problem categories and their accumulated frequency reflected in investigation are shown in table 1 . 
TABLE I. STATISTICS OF PROBLEM PHENOMENA CATEGORY AND THEIR CUMULATIVE FREQUENCY

\begin{tabular}{|c|c|c|c|}
\hline Stage & Category & $\begin{array}{c}\text { Subcategory } \\
\text { amount }\end{array}$ & Frequency \\
\hline \multirow{4}{*}{$\begin{array}{l}\text { Decision- } \\
\text { making stage }\end{array}$} & Project plan & 7 & 95 \\
\hline & Investigation & 2 & 45 \\
\hline & $\begin{array}{c}\text { Feasibility } \\
\text { analysis }\end{array}$ & 6 & 136 \\
\hline & $\begin{array}{c}\text { Approval } \\
\text { process }\end{array}$ & 7 & 189 \\
\hline \multirow{6}{*}{ Arranged stage } & $\begin{array}{c}\text { Organization } \\
\text { establishment }\end{array}$ & 6 & 123 \\
\hline & $\begin{array}{c}\text { Engineering } \\
\text { design }\end{array}$ & 19 & 440 \\
\hline & Bid & 15 & 551 \\
\hline & $\begin{array}{c}\text { Engineering } \\
\text { preparation }\end{array}$ & 11 & 310 \\
\hline & $\begin{array}{c}\text { Handle } \\
\text { procedures }\end{array}$ & 4 & 214 \\
\hline & $\begin{array}{c}\text { Mutual } \\
\text { cooperation }\end{array}$ & 15 & 430 \\
\hline \multirow{7}{*}{$\begin{array}{l}\text { Construction } \\
\text { stage }\end{array}$} & Risk & 14 & 278 \\
\hline & Quality & 26 & 534 \\
\hline & Schedule & 27 & 540 \\
\hline & Cost & 13 & 537 \\
\hline & Safety & 30 & 488 \\
\hline & $\begin{array}{c}\text { Environment } \\
\text { protection }\end{array}$ & 23 & 283 \\
\hline & Resource supply & 11 & 332 \\
\hline \multirow{5}{*}{$\begin{array}{l}\text { Conclusion } \\
\text { stage }\end{array}$} & $\begin{array}{l}\text { Checking and } \\
\text { accepting }\end{array}$ & 8 & 356 \\
\hline & Settlement & 9 & 322 \\
\hline & Pre-running & 4 & 124 \\
\hline & Handover & 3 & 163 \\
\hline & Other tasks & 5 & 321 \\
\hline
\end{tabular}

\section{Distribution ANALysis of All Problem PhenOMENA In EVERY STAGE}

It can be seen from table 1 that the subcategory amounts and frequency of all kinds of problem phenomena in every stage are very different, this means that different problem would bring different degree's affection to project. It can be sure that the problems which often happen will bring more disadvantage and restriction to project development, and must consume more project resources, so, these problems are just major problems. This characteristic shows there is a kind of primary and secondary relationship among these problem phenomena. If we want to reveal these primary and secondary relationships, the distribution regulations of all kinds of problem phenomena in every stage should be analyzed and described firstly.

In table 1, all problem phenomena in decision-making stage are divided into four kinds, which are project plan, investigation, feasibility analysis and project's approval process. In these categories, there are 7 subcategories in project plan, their accumulated frequencies are 95; there are 2 subcategories in investigation, their accumulated frequencies are 45; there are 6 subcategories in feasibility analysis, their accumulated frequencies are 136; there are 7 subcategories in project approval process, their accumulated frequencies are 189. According to these data, we can describe them as figure 1 by statistics and Luos paslik model [4-5]. Similarly, according to the same method and combine with table 1 , the distribution states of problem phenomena in other stages can also be obtained as follow from figure 2 to 4 .

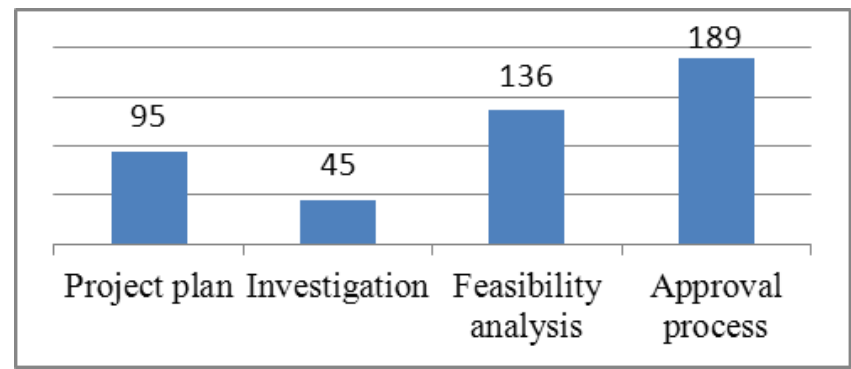

FIGURE I.DISTRIBUTION OF PROBLEM PHENOMENA

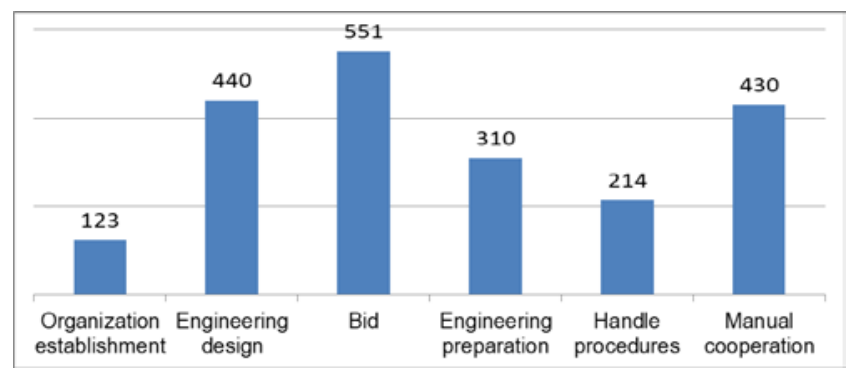

FIGURE II. DISTRIBUTION OF PROBLEM PHENOMENA IN ARRANGED STAGE IN DECISION-MAKING STAGE

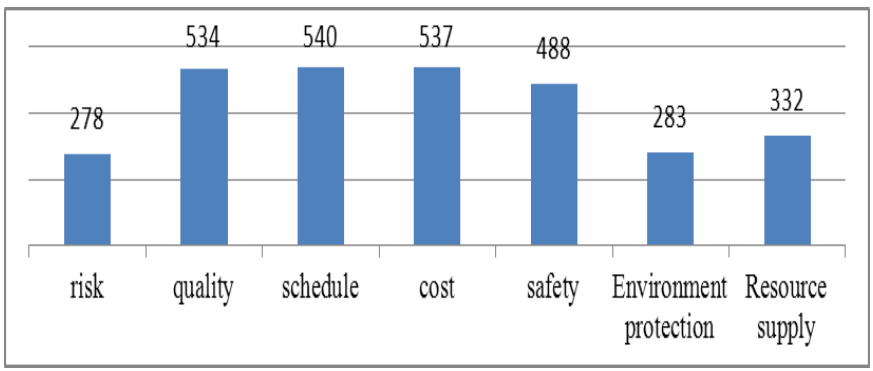

FIGURE III. DISTRIBUTION OF PROBLEM PHENOMENA IN CONSTRUCTION STAGE

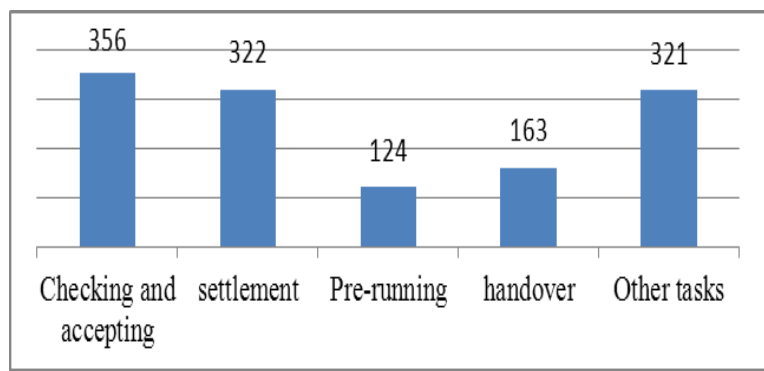

FIGURE IV.

DISTRIBUTION OF PROBLEM PHENOMENA IN CONCLUSION STAGE

According to above analysis results together with the task of different stage, some conclusions can be draw as follow.

1) In decision-making stage, the occurred problem phenomena mostly concentrate on the face of inefficient decision-making. They are often shown in such forms as overtime making-decision, delay of project plan or taking too long times in project approval process. 
2) In arranged stage, the occurred problem phenomena often concentrate on the face of unfair competition in bid, disobeying standards in design, unsuccessful project financing, complicated project procedures, etc.

3) In construction stage, although a large amount of problem phenomena are shown in such forms as bad quality, delay in schedule, high cost or safety accidents and so on, in fact, they prove that there are many such problems as inconsistent action, disordered management, unconscionable individual behaviors, breach of duty and so on in the stage.

4) In conclusion stage, the main problems concentrate on project settlement or engineering checking and accepting. But it can be known from the investigation results that the default in fund payment has become the most troublesome problem at present.

\section{Total Distribution of Problem Phenomena}

It can be known from above analysis of problem phenomena in four stages that the frequencies of problem phenomena in every stage are very different. If there are many problem phenomena in one stage, their accumulated frequencies are also higher, the total representation degree must be greater, and more project resource for solving them would be consumed too. So, finding out and master their total distributions of problem phenomena in engineering project is very important for managing project problems and optimizing project resources.

Here, let all problem phenomena in projects as a parent population. If we compartmentalize the parent population by four stages in engineering project, the four stages are just subsets of the parent population[6]. According to table 1 , the four subsets' sub-sample capacitance of cumulative frequencies is respectively 465, 2068, 2992 and 1286. Similarly, according to above same method and the four subsample capacitance, the total distribution state of problem phenomena in engineering can be obtained, and it can be shown as table 2 and figure 5 .

TABLE II. TOTAL DISTRIBUTIONS OF PROBLEM PHENOMENA IN CEP

\begin{tabular}{|c|c|c|c|}
\hline Number & Stage & $\begin{array}{c}\text { Accumulated } \\
\text { Frequencies }\end{array}$ & $\begin{array}{c}\text { Frequencies } \\
\text { rate }\end{array}$ \\
\hline A & $\begin{array}{c}\text { Decision- } \\
\text { making }\end{array}$ & 465 & $7 \%$ \\
\hline B & $\begin{array}{c}\text { Arranged } \\
\text { stage }\end{array}$ & 2068 & $30 \%$ \\
\hline C & $\begin{array}{c}\text { Construction } \\
\text { stage }\end{array}$ & 2992 & $44 \%$ \\
\hline D & $\begin{array}{c}\text { Conclusion } \\
\text { stage }\end{array}$ & 1286 & $19 \%$ \\
\hline Total & & 6811 & 100 \\
\hline
\end{tabular}

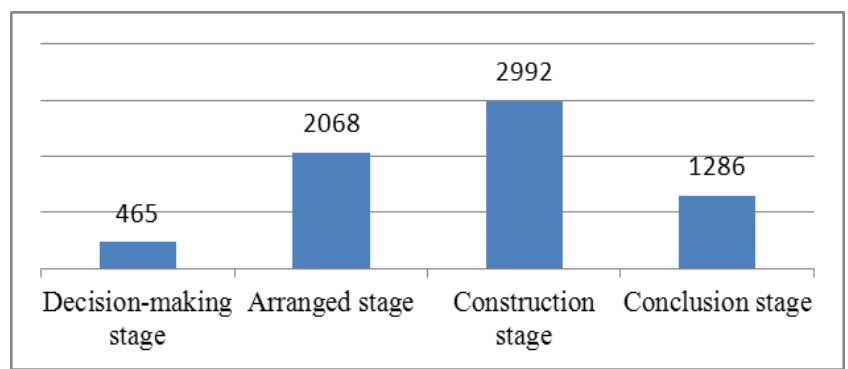

FIGURE V.

TOTAL D OF PROBLEM PHENOMENA

Seeing from table 2, the cumulative frequencies of problem phenomena in construction stage come to a head in CEP. The amount in engineering stage is almost a half of quantity of all problem phenomena. Although the value could not be sure as absolute rate at least, it reflects the real distribution state of problem and a real relative rate in engineering projects as a whole. The most important of all is that the result provides a reliable and confirmatory evidence for project managers to arrange their jobs reasonably, forecasting project problems scientifically, controlling whole project as well as planning and optimizing project resources efficiently, so, the research result has very high value in project management.

\section{CONCLUSIONS}

It can be known from above research results that the distributions of problem phenomena in CEP are regular although they have a characteristic of variety on the surface. Especially, some following regulations are very important to project managers.

(1) All problem phenomena correlate with their stage characteristics, their corresponding plans and objects tightly. This result can offer science evidences for project managers forecasting problem phenomena in projects.

(2) Because unconscionable individual behaviors often happen in engineering project, and they closely connected with the success of the project, project managers must forbid such behaviors if they want to realize project targets smoothly.

(3) The amount of problem phenomena in construction stage is the maximum in CEP. This means they would consume lots of project resources, so, project managers should make resources scheme in advance in order to avoid resource conflict.

(4) The problem phenomena amount will obviously increase from decision-making stage to arranged stage. The result warns that project managers should make sufficient ready for solving some problems in advance.

\section{ACKNOWLEDGMENT}

This study was supported by the national natural science foundation of China (Grant No. 71171081) and the natural science foundation of Beijing (Grant No. 9162014).

\section{REFERENCES}

[1] H. Mohamed, T. Apollo. 2016. A Problem Solving Approach to Identifying Civil Engineering Infrastructure Projects. Proceedings of the 32nd Annual ARCOM Conference, p. 853-862. 
[2] J.X. Li. 2014. Methods and Measures of Project Cost Implementation and Control on All the Stages of Engineering Project. Proceedings of the 4th International Conference on Green Building, Materials and Civil Engineering, p. 539-542.

[3] T.F. Zhu, Z.Y. Yang. 2013. Meteorological Data Based on Apriority Algorithm. Lecture Notes in Electrical Engineering Vol.27, p. 235-241.

[4] J.S. Lin, C.H. Dou. 2017. A Novel Method for Condition Monitoring of Rotating Machinery Based on Statistical Linguistic Analysis and Weighted Similarity Measure. Journal of Sound and Vibration Vol. 390, p. 272-288.

[5] Z. Chen, X.M. Huo, Z.R. Qiu. 2017. Solution Identification and Quantitative Analysis of Fiber-Capacitive Drop Analyzer Based on Multivariate Statistical Methods. Review of Scientific Instruments Vol. 88, p. 148-152.

[6] O. Anton, E. Ershov. 2017. Statistical Analysis of the Characteristics of High Degree Polynomial Solving Methods Used in the Five-Point Algorithm. International Conference on Optical Engineering, p. 102-108. 